\title{
Plasticity of Alarm-call Response Development in Belding's Ground Squirrels (Spermophilus beldingi, Sciuridae)
}

\author{
Jill M. Mateo \& Warren G. Holmes
}

Mateo, J. M. \& Holmes, W. G. 1999: Plasticity of alarm-call response development in Belding's ground squirrels (Spermophilus beldingi, Sciuridae). Ethology 105, 193-206.

\begin{abstract}
Plasticity in the alarm-call responses of Belding's ground squirrels (Spermophilus beldingi) may function to prepare young to respond appropriately to calls according to the predator environment and habitat in which the young develop. To examine the extent to which antipredator responses are sensitive to early rearing environments, we studied the development of behavioural responses to playbacks of alarm calls and non-alarm calls in free-living juveniles and captive juveniles housed in large outdoor enclosures. Compared with same-aged, free-living juveniles, captive juveniles were more likely to show an observable response to playbacks, exhibited more exaggerated initial responses (e.g. enter a burrow vs. freeze), and remained alert longer following playbacks. The influence of rearing history on antipredator responses was limited to responses to auditory stimuli, as the two groups of juveniles reacted similarly to fastmoving visual stimuli. The responses of free-living juveniles appeared to be more discriminating than responses of captive juveniles, particularly following playbacks of calls associated with less immediate threats.

The responses of captive and free-living mothers were similar, indicating a developmental component to the juvenile response differences observed here. Freeliving juveniles developed a discrimination among alarm and non-alarm calls sooner than captive young. Response differences were evident within $1 \mathrm{wk}$ of first emergence from natal burrows and persisted at least $4 \mathrm{wk}$, at around the age of natal dispersal. This suggests that early rearing history has an enduring effect on response repertoires, which may be adaptive if animals continue to inhabit the predator environment in which they developed.
\end{abstract}

Corresponding author: J. M. Mateo, Department of Psychology, 229 Uris Hall, Cornell University, Ithaca, NY 14853-7601, USA. E-mail: jmm52@cornell.edu

\section{Introduction}

One of the hallmarks of vertebrate behavioural development is its sensitivity to the local environmental context in which development occurs. From a functional

U. S. Copyright Clearance Center Code Statement: 0179-1613/99/1053-0193\$14.00/0 
perspective, such sensitivity makes adaptive sense if one views juvenile behaviour patterns as ontogenetic or age-specific adaptations (Galef 1981; Alberts 1987) and recognizes that the factors which influence survival and reproduction in one environment will often differ from those in another environment. In some species of fishes, for example, the intensity of predation varies considerably between populations and both juvenile and adult antipredator behaviour patterns differ between populations depending on the animals' experiences during early development (Goodey \& Liley 1986; Tulley \& Huntingford 1987; Magurran 1990). Such developmental plasticity, or the modifiability of behaviour as a result of specific experiences or environmental conditions, is not surprising given that predation can be such a potent selective agent on both juveniles and adults (Endler 1991, 1995).

Alarm calls are vocal responses elicited by predators that can alert other animals to impending danger (Klump \& Shalter 1984). We have conducted a series of controlled studies with Belding's ground squirrels (Spermophilus beldingi) to explain the development of species-typical responses to alarm calls (Mateo 1995, 1996b; Mateo \& Holmes 1997) and have proposed that one function of S. beldingi response plasticity is to facilitate the development of behavioural patterns that are appropriate to the local predator environment (Mateo 1996a,b; see also Magurran (1990) and Endler (1995)). In this paper, we report results of a playback study designed to examine the extent to which alarm-call response development in $S$. beldingi is sensitive to differences in environmental context, as outlined above. By comparing free-living and captive (housed in large outdoor enclosures) young during their initial week after emergence from their natal burrow and throughout the remainder of the summer, we could examine whether the process of behavioural development is mediated by the unique features of an individual's ontogenetic niche. We chose such dissimilar environments (a field and a captive environment) for this initial comparison to amplify any potential effects of early rearing history on alarm-call response development. If developmental differences did not arise in young reared in these two environments, it would indicate the existence of minimal plasticity in $S$. beldingi alarm-call response development as a function of early rearing experiences.

Another reason for comparing field-reared and captive-reared young was that it allowed us to determine the ecological validity of our captive-rearing and captivetesting environments (e.g. Mateo \& Holmes 1997). Because antipredator behaviour can be affected by an organism's rearing environment as well as its current environment (e.g. Poran \& Coss 1990; Brown et al. 1992; Miller 1994), we wanted to determine whether we were observing in our captive animals the species-typical responses that characterize free-living juvenile $S$. beldingi behaviours. Some investigators have compared the behaviour of free-living and captive animals using consistent methodologies and behavioural criteria in both environments (e.g. Rowell 1967; Beecher 1996), but few have systematically examined how early rearing environments affect the development of survival skills such as antipredator behaviour. Therefore, in this study we compared the alarm-call responses of free-living juveniles with same-aged captive juveniles to determine how the rate of development and the expression of responses are affected by juvenile rearing environ- 
ments. In a companion paper (Mateo \& Holmes 1999), we test a variety of hypotheses about the specific rearing experiences that might mediate the response differences we report below.

Belding's ground squirrels are group-living diurnal rodents that live in alpine and subalpine habitats throughout the Sierra Nevada and southern Cascade mountains (Jenkins \& Eshelman 1984). Mothers rear their young (litter size = 3-6 pups; Sherman \& Morton 1984) in underground burrows for about 25-28 d, after which their nearly weaned young come above ground for the first time as juveniles (their 'natal emergence'; Sherman 1976). Juveniles continue to reside and interact with their mother during the 4-6 wk prior to natal dispersal and hibernation. Predation can account for up to $60 \%$ of juvenile mortality during the first summer of life (Sherman \& Morton 1984) and overwinter survival in ground squirrels depends on the accumulation of body fat prior to hibernation (Murie \& Boag 1984; Trombulak 1991).

Spermophilus beldingi predators, including coyotes (Canis latrans), badgers (Taxidea taxus), long-tailed weasels (Mustela frenata), and various species of raptors (Buteo, Accipiter, Falco), elicit two types of alarm calls from adults (Sherman 1977; Robinson 1980; pers. obs.). Trills are elicited by slow-moving predators or predators that pose no immediate threat, and whistles are elicited by fast-moving predators or those that pose an immediate threat (Sherman 1977, 1985; Robinson 1981; Leger et al. 1984). Trills typically cause adults to post (a bipedal stance) and visually scan the area for what evoked the call, whereas whistles prompt animals to run to the nearest burrow, often entering the refuge (Sherman 1977, 1985; Robinson 1981; Mateo 1996b). At natal emergence, juveniles do not display differential behavioural responses to trills and whistles, nor do they discriminate behaviourally between alarm and non-alarm calls. However, alarm-call discrimination develops within $5 \mathrm{~d}$ of natal emergence, and is facilitated by exposure to calls and by juveniles' observations of conspecifics' responses. The pattern of responses (initial response, response duration, vigilant postures) continues to develop during the following 4-6 wk before autumnal immergence (Mateo 1996b; Mateo \& Holmes 1997).

In this study, we compared the behaviour patterns of free-living and captive juveniles to identify possible differences in the development of their alarm-call responses. Such differences could result from the two very different rearing and/or testing environments experienced by our study animals (Miller 1981, 1994; Brodie 1993). For example, after natal emergence free-living juveniles were exposed to predators and natural alarm calls at a higher rate than their captive counterparts. In addition, a free-living juvenile's first above-ground exposure to an alarm call may have occurred in the absence of a mother that is foraging well away from her offspring (see also Owings \& Coss (1977) and Mateo (1996b)). Captive juveniles and their mothers, on the other hand, were provided with food and shelter, and thus did not experience the species-typical pressures of foraging and predation risks. Finally, burrows for captive juveniles were visible throughout the enclosure, whereas microtopographic features may have obscured burrows in the field or forced individuals to run circuitously to reach a refuge. 


\section{Methods}

\section{Animals}

We observed both free-living and captive juveniles between Jun. and Aug. 1993 from natal emergence (around $25 \mathrm{~d}$ of age; Sherman 1976) until $\approx 50 \mathrm{~d}$ of age. We marked each animal with a unique combination of dye marks (blue-black; Lady Clairol Co.) and coloured ear tags. For analyses, data were grouped into three age cohorts, which were based on recognizable behavioural changes displayed by free-living juveniles (Mateo 1996b): days 1-5 post-emergence when juveniles spend most of their time within $5 \mathrm{~m}$ of the natal burrow; days 6-15 when juveniles begin to explore the surrounding meadow but the natal burrow remains the centre of activity; and days 16-25, before natal dispersal activity begins (Holekamp 1984). We refer to these three groupings as age cohorts, although our labels refer not to days since birth, but rather to days since natal emergence.

\section{Study Sites \\ Free-living animals}

We studied 65 juvenile $S$. beldingi from 13 litters at a site within the 4 ha Lower Horse Corral in Rock Creek Canyon, Mono Co., CA, USA (2900 m elevation). The main site $(30 \times 91 \mathrm{~m})$ was typical of Eastern Sierra subalpine meadow habitat. We sexed, weighed, and marked juveniles within 1-2 d of their natal emergence (see Mateo (1996b) for details).

\section{Captive animals}

We studied four groups of captive juveniles (two litters/group; $n=40$ juveniles) at the Sierra Nevada Aquatic Research Laboratory (SNARL), located near Mammoth Lakes, CA, USA $(2100 \mathrm{~m})$. To acquire these animals, we trapped their field-mated mothers from four populations within $100 \mathrm{~km}$ of SNARL. We housed females in a nursery building at SNARL and provided each with her own nestbox $(28 \times 20 \times 20 \mathrm{~cm})$ filled with wood shavings in which the mothers gave birth and reared their young. Each nestbox had a $6 \mathrm{~cm}$ diameter entry hole and a removable top and was placed inside a stainless steel cage $(61 \times 45 \times 35 \mathrm{~cm})$. The females were in captivity for about $1 \mathrm{wk}$ before parturition (range $=3-10 \mathrm{~d}$ ). The building was maintained at about $20^{\circ} \mathrm{C}$ on a 13:11 light:dark schedule. We gave the mothers water ad libitum and Purina mouse chow (5015; $\approx 20 \mathrm{~g} / \mathrm{d}$ ), which we occasionally supplemented with sunflower seeds and fresh vegetables. We sexed the pups the day after birth and inspected and weighed them every $5 \mathrm{~d}$.

\section{Outdoor enclosures}

To conduct playback experiments on captive $S$. beldingi, we transferred a group of animals and their mothers in their nestboxes to an outdoor enclosure (two litters/group, $\approx 4-6$ pups/litter) when the young were 23-24 d of age. Each of four $9.7 \times 9.7 \times 1.6 \mathrm{~m}$ open-air enclosures included natural vegetation, food 
and water stations and tunnel systems (see Holmes (1994) for details). Nestboxes (see above) were placed about $10 \mathrm{~cm}$ below ground and connected to the ground surface by buried plastic pipes. We provided eight 'burrows' as refuge, including partially buried single-entrance pipes and two-entrance pipes laid on the surface of the enclosure (for details see Mateo \& Holmes (1997)). The $1.6 \mathrm{~m}$ high opaque plywood walls of the enclosures limited the animals' visual fields to what they could observe inside the enclosure or see overhead. At the completion of each study, we released the juveniles with their mother at the site where we originally trapped the mother.

\section{Playback Stimuli}

We used four categories of auditory playbacks: two types of $S$. beldingi alarm calls (single whistles and trills; Robinson 1981; Leger et al. 1984), one S. beldingi squeal category and one house wren, Troglodytes aeodon, song category. We used two additional vocalizations, squeals and wren songs, as control stimuli to record the development of juvenile responses to common auditory stimuli that are not associated with predator contexts. Juveniles frequently squeal during rough play or during agonistic encounters with adults (pers. obs.; Sherman 1977). Although squeals may be associated with aversive situations, they are typically emitted in non-predatory contexts and are not elicited by visual stimuli alone (e.g. an approaching adult); therefore, squeals are not antipredator calls. House wrens are sympatric with $S$. beldingi, and their songs are also not associated with predatory contexts. We also included an 'aerial-object' category to record responses to a single-whistle call paired with a fast-moving visual stimulus (a frisbee flown 2-4 m over the head of an individual 1-2 s after presentation of the alarm call; Mateo 1996b). Thus, we used a total of five playback categories, four of which included only an auditory stimulus and one of which included an auditory and visual stimulus. For some analyses we grouped the auditory stimuli into alarm calls (single whistle and trill) and non-alarm calls (squeal and wren song).

To acquire playback stimuli, we recorded calls with a Sony TC-D5M stereo cassette recorder and AKG condenser microphone (SE 5-10), from a distance of 6-9 $\mathrm{m}$ from the vocalizing animal (details on recording and filtering of calls can be found in Mateo (1996b) and Mateo \& Holmes (1997)). Recordings were obtained from adults from three populations in 1990 and 1992, and were supplemented by some calls recorded by D. Leger (see Leger et al. (1984)). All recordings were from animals in populations other than the ones studied here. We played the recordings through either a Sony TC-D5M or Sony WM-D6C cassette recorder/player connected to a Nagra DH amplifier-speaker. All playbacks were presented at peak amplitudes approximating natural intensities (whistles $\approx 85 \mathrm{~dB}$, trill $\approx 75 \mathrm{~dB}$, squeal $\approx 50 \mathrm{~dB}$ and wren song $\approx 60 \mathrm{~dB}$; measured with a Realistic sound level meter on ' $\mathrm{A}$ ' weighting at $9 \mathrm{~m}$ from the speaker, the distance at which we measured naturally occurring calls). We used eight exemplars of each stimulus, selected for their signal amplitude and signal/noise ratio, and recorded each exemplar within a category from a different individual. 


\section{Playback Protocol}

For both free-living and captive juveniles, we conducted playbacks daily between 07.00 and $11.00 \mathrm{~h}$ or 15.00 and $18.00 \mathrm{~h}$, beginning when the juveniles were $25 \mathrm{~d}$ old (around their natal emergence) and continuing until the juveniles were $\approx 50 \mathrm{~d}$ old. We conducted one or two playback sessions per day to each group. A playback session consisted of one playback of one exemplar of each of the five playback categories (presented in a balanced order, except for aerial-object playbacks, which were presented last during each session) and each session lasted about $2 \mathrm{~h}$. We presented one exemplar about every $15 \mathrm{~min}$, unless we heard a natural alarm call or saw a potential predator during the preceding interval. Both captive and free-living $S$. beldingi continued to respond in a species-typical manner to natural and recorded alarm calls throughout all studies (Mateo 1995), indicating that our playback schedule minimized habituation to the playbacks. We videotaped the animals' responses to playback stimuli from $3 \mathrm{~m}$ high viewing stands, using either a Panasonic AG 450 VHS camera with a $10 \times$ zoom lens or a Sony CCDF35 $8 \mathrm{~mm}$ camcorder with a $6 \times$ zoom lens.

Before each playback, we randomly selected a focal ground squirrel and began taping when that individual was above ground and $\geqslant 1 \mathrm{~m}$ from a burrow. Each individual served as a focal for each playback category at least once and was videotaped at least every other day. We taped the focal ground squirrel from $15 \mathrm{~s}$ prior to stimulus onset until it resumed a non-alert behaviour, such as feeding or socializing. For captive groups, we fixed a second camcorder on a burrow entrance to videotape the responses of non-focal individuals that were near that burrow or that ran to it. The use of multiple cameras in both environments allowed us to record the responses of two or three juveniles in addition to the focal juvenile, and thus increased our sample sizes without conducting additional playbacks each day (which could possibly habituate the animals to the playbacks).

\section{Behavioural Response Measures}

We quantified playback responses from videotapes using ETHOS22 eventrecorder software (G. Gerstner, University of Michigan). This program allowed us to summarize the frequencies and durations (to the nearest $0.01 \mathrm{~s}$ ) of six alert behaviour patterns (horizontal, slouch, posting, and vertical-stretch postures (defined in Mateo (1996b)), below ground, and running) and four non-alert behaviour patterns (stationary, feeding, grooming, and socializing; Mateo 1995).

We then derived three response measures for each individual's response to a playback: 1. 'Responsivity' indicated whether an individual displayed an observable response to a playback, typically presented as the proportion of individuals exhibiting any detectable reaction to a stimulus; 2. 'Initial response' was the respondent's first reaction to a playback, categorized as entering a burrow, running to a burrow, posting, or freezing (or raising head); 3. 'Response duration' was the total time exhibiting any of the six alert behaviour patterns (above), measured from the beginning of a response (typically concurrent with stimulus onset) until the individual resumed a non-alert behaviour. Response durations were normally distributed. 


\section{Analyses}

We used each individual's reaction to each playback as the unit of analysis for each of the three response measures, because between-individual response variation never exceeded within-individual variation. However, to minimize potential effects of data independence, we limited the data sets to one presentation of each playback category per individual per age cohort. Although we often recorded the responses of non-focal as well as focal ground squirrels to a single playback, or the response of more than one individual from a litter, we included all responses in our analyses. We did so because we did not find that the responses of multiple juveniles to one playback, or the responses of littermates (young born to a common mother) to all playbacks, were statistically dependent. (See Mateo (1996b) for a discussion of response independence and Martin \& Bateson (1986) and Leger \& Didrichsons (1994) for a general discussion of data pooling and litter effects.)

To examine behavioural differences between groups prior to playbacks, we calculated the percentage of time each juvenile engaged in each of 10 possible behaviours (see alert and nonalert behaviour patterns above). Because these proportions assumed Poisson distributions, we analysed them with log-linear models controlling for sex and age (see Holmes (1994) for details on log-linear models). We found no significant differences between captive and free-living juveniles in pre-playback behavioural patterns, nor did we find significant variation in preplayback behaviours among the five playback categories (all $\mathrm{p}>0.05$ ). To determine whether the juveniles' responses varied across auditory exemplars within a playback category, we conducted a one-way ANOVA on the response-duration data following each of the eight exemplars for each playback category. None of the tests revealed significant variation $(\mathrm{p}>0.05)$ so we pooled data from the eight exemplars for each playback category. Finally, we found no significant difference in responsivity, initial responses or response duration by animals originating from different populations (see Captive animals) so we pooled their data when analyses were based on groups of such individuals. For all $\chi^{2}$ analyses, we used Yates' correction for continuity when $\mathrm{df}=1$. For all ANCOVAs, the covariate was juvenile age (response duration is negatively correlated with age; Mateo 1996b). We considered results significant when $\mathrm{p}<0.05$, and present the data as $\overline{\mathrm{X}} \pm$ standard error (SE).

\section{Results}

\section{Responsivity}

Based on combined data from the three age cohorts (see Methods), captive juveniles were significantly more likely than free-living juveniles to show some observable response to playbacks of both alarm calls $\left(\chi^{2}=6.04 ; \mathrm{df}=1 ; \mathrm{p}<0.05\right)$ and non-alarm calls $\left(\chi^{2}=5.92 ; \mathrm{df}=1 ; \mathrm{p}<0.05\right.$; Fig. 1a). There was no difference in responsivity during days $1-5$ (alarm calls: $\chi^{2}=0.21$; non-alarm calls: $\chi^{2}=0.82$; both $\mathrm{df}=1$; ns). However, captive juveniles were significantly more likely to respond to both alarm calls and non-alarm calls by days $6-15\left(\chi^{2}=3.90\right.$ and 6.67 , respectively; both $\mathrm{df}=1$ and $\mathrm{p}<0.05)$. When analysed by playback category, 

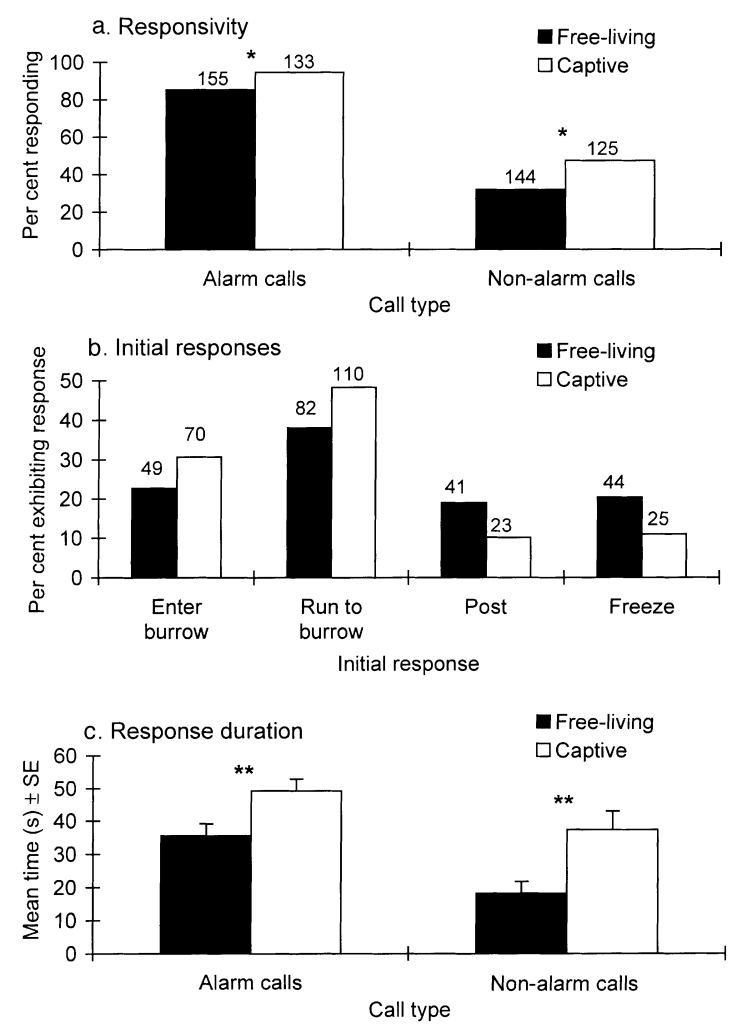

Fig. 1: Comparison of responses by free-living and captive juveniles to playbacks of alarm calls (Spermophilus beldingi single whistle and trill) and non-alarm calls (wren song and $S$. beldingi squeal). Data are grouped by call type and all age cohorts are combined. See text for details of analyses. a. Proportion of juveniles exhibiting some type of observable response following each call type. The numbers above the bars represent the total number of responders and non-responders. Asterisks represent significant differences (Yates' $\chi^{2} ; \mathrm{p}<0.05$ ) in responsivity by free-living and captive juveniles. $\mathrm{b}$. Percentage of free-living and captive juveniles responding to playbacks with each of four initial-response types. Data from alarm-call, non-alarm-call, and aerial-object (frisbee paired with single-whistle alarm call) playbacks are pooled. The numbers above the bars represent the number of times juveniles exhibited that initial-response type. See text for discussion of significant contrasts $(\mathrm{p}<0.05)$ between free-living and captive juveniles based on partitioned $\chi^{2}$ analyses. c. Juvenile response durations $(\overline{\mathrm{X}} \pm$ standard error (SE) s), measured from presentation of playback until non-alert behaviour was resumed. Data are adjusted for juvenile age. Asterisks represent significant differences $(p<0.01)$ in response durations between free-living and captive juveniles

captive juveniles were more likely than free-living juveniles to respond to single whistles and squeals (Table 1), but not to the three other playback categories.

\section{Initial Responses}

We conducted $4 \times 2 \chi^{2}$ analyses on initial responses (enter a burrow, run to a burrow, post or freeze/look) to compare the frequency of response types exhibited by juveniles reared in the two environments. Initial responses differed following 
Table 1: Proportion (\%) of free-living and captive juveniles responding to playback stimuli*

\begin{tabular}{|lccc|}
\hline Stimulus & Free-living & Captive & Yates' $\chi^{2}$ \\
\hline Single whistle & $68 / 84(81.0)$ & $87 / 94(92.6)$ & $4.32, \mathrm{p}<0.05$ \\
Trill & $65 / 71(91.6)$ & $91 / 95(95.8)$ & $0.65, \mathrm{~ns}$ \\
Squeal & $28 / 65(43.1)$ & $58 / 87(66.7)$ & $7.49, \mathrm{p}<0.01$ \\
Wren song & $18 / 79(22.8)$ & $25 / 85(29.4)$ & $0.43, \mathrm{~ns}$ \\
Aerial object† & $34 / 36(94.4)$ & $50 / 50(100)$ & ns $\nleftarrow$ \\
\hline
\end{tabular}

*All age cohorts combined. $†$ Single-whistle alarm call paired with frisbee. $\ddagger$ Fisher’s exact test.

alarm calls $\left(\chi^{2}=16.79 ; \mathrm{df}=3 ; \mathrm{p}<0.01\right)$ but not non-alarm calls $\left(\chi^{2}=3.74\right.$; $\mathrm{df}=3$; ns). When we analysed all playback categories together (including aerialobject playbacks; $\chi^{2}=17.77$; $\mathrm{df}=3 ; \mathrm{p}<0.001$ ), the partitioned tables indicated that as their initial response to a playback, captive juveniles were significantly more likely to run to a burrow, whereas free-living young were more likely to post or to freeze (Fig. 1b).

\section{Response Duration}

Captive juveniles remained alert longer than same-aged free-living juveniles following alarm calls (ANCOVA $\mathrm{F}=7.64$; $\mathrm{df}=1,253 ; \mathrm{p}<0.01$ ) and non-alarm calls (ANCOVA $\mathrm{F}=7.82$; $\mathrm{df}=1,100 ; \mathrm{p}<0.01$; Fig. 1c). The difference in response duration following alarm calls was not significant until days 6-15 and days 16 $25(\mathrm{t}=2.38 ; \mathrm{df}=135$ and $\mathrm{t}=2.31 ; \mathrm{df}=89$, respectively; both $\mathrm{p}<0.05)$. When analysed by playback category, the captive juveniles had significantly longer response durations than free-living juveniles following trill and squeal playbacks (the difference following wren-song playbacks approached significance; Table 2).

\section{Development of Responsivity}

On their 1st day above ground, neither free-living nor captive juveniles reacted differentially to alarm calls and non-alarm calls, although free-living juveniles had begun to differentiate between call types (free-living juveniles: $\chi^{2}=3.57$; $\mathrm{df}=1$; $\mathrm{p}<0.10$; captive juveniles: Fisher's exact test, ns; Fig. 2). By their 2 nd day above ground, free-living juveniles responded selectively to alarm calls ( $\mathrm{p}<0.05$ for days $2-5)$. In contrast, captive juveniles did not exhibit a statistical discrimination until their 3rd day above ground ( $\mathrm{p}<0.05$ for days $3-5)$.

\section{Mothers' Responses}

We observed no differences between captive (housed at SNARL for 4-6 wk) and free-living mothers in responsivity (alarm calls: $\chi^{2}=0.19$; non-alarm calls: $\chi^{2}=0.73$; both $\mathrm{df}=1$ and $\mathrm{ns}$ ). Nor did mothers differ in their response durations 
Table 2: Response durations of captive and free-living juveniles, adjusted for age

\begin{tabular}{|c|c|c|c|c|}
\hline Stimulus & $\begin{array}{l}\text { ANCOVA, F } \\
\text { ratio (df) }\end{array}$ & $\mathrm{p}$ & Group & $\underset{\left(n^{*}\right)}{\operatorname{Duration} \bar{X}} \pm$ SE s \\
\hline \multirow[t]{2}{*}{ Single whistle } & $1.04(1,128)$ & 0.31 & captive & $40.0 \pm 3.5(62)$ \\
\hline & & & free-living & $32.8 \pm 6.0(69)$ \\
\hline \multirow[t]{2}{*}{ Trill } & $8.09(1,122)$ & 0.01 & captive & $58.2 \pm 6.4(62)$ \\
\hline & & & free-living & $39.0 \pm 3.6(63)$ \\
\hline \multirow[t]{2}{*}{ Squeal } & $4.61(1,61)$ & 0.04 & captive & $37.7 \pm 6.3(37)$ \\
\hline & & & free-living & $16.8 \pm 3.3(27)$ \\
\hline \multirow[t]{2}{*}{ Wren song } & $3.71(1,36)$ & 0.07 & captive & $49.0 \pm 10.9(21)$ \\
\hline & & & free-living & $33.5 \pm 8.1(18)$ \\
\hline \multirow[t]{2}{*}{ Aerial object $\dagger$} & $0.81(1,72)$ & 0.37 & captive & $125.0 \pm 11.1(43)$ \\
\hline & & & free-living & $107.8 \pm 14.9(32)$ \\
\hline
\end{tabular}

$* \mathrm{n}=$ number of responses. $†$ Single-whistle alarm call paired with frisbee. SE, standard error.

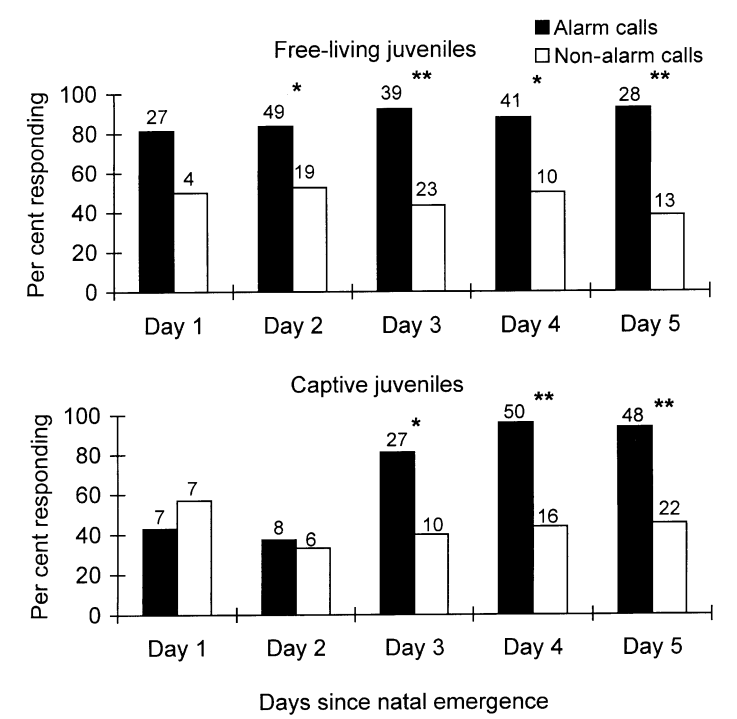

Fig. 2: Percentage of newly emergent free-living (top) and captive (bottom) juveniles exhibiting a response to alarm-call and non-alarm-call playbacks on their 1 st to 5 th day above ground. The numbers above the bars represent the total number of responders and non-responders. Asterisks represent significant differences (Yates' $\chi^{2} ;{ }^{*} \mathrm{p}<0.05,{ }^{* *} \mathrm{p}<0.01$ ) in responsivity to alarm calls and non-alarm calls

(all playback categories combined; ANCOVA, correcting for juvenile age; Mateo 1996b: $\mathrm{F}=0.94$; $\mathrm{df}=1,47$ ). However, the initial responses to playbacks differed for the two types of females: captive mothers were more likely to run to a burrow 
(64.3\% of 28 initial responses), whereas free-living mothers commonly posted (59.1\% of 22 responses; overall $\chi^{2}=12.97$; $\mathrm{df}=3$; $\left.\mathrm{p}<0.001\right)$.

\section{Discussion}

Comparisons between captive Belding's ground squirrel juveniles, reared in a nursery building and subsequently observed in outdoor enclosures, and freeliving juveniles, reared and observed in the field, revealed some quantitative but no qualitative differences in alarm-call response behaviour. For example, juveniles reared in one environment displayed a more intense response at an earlier age than juveniles reared in another environment, a quantitative difference examined below, but the kinds of responses displayed by juveniles from both environments were similar. These results demonstrate an effect of the early environment on the ontogeny of alarm-call response behaviour in young ground squirrels and highlight the plastic nature of such behavioural development. The lack of qualitatively different responses also verifies the ecological validity of the methods we used to study $S$. beldingi development.

What quantitative differences distinguished free-living from captive young? Captive juveniles were more likely to respond to playbacks, remained alert longer, and ran to a refuge more often than same-aged, free-living juveniles (Fig. 1a-c). However, the difference in the juveniles' response durations was only significant following playbacks indicative of less urgent contexts (trills, squeals, and to a lesser extent, wren songs; Table 2), suggesting that free-living juveniles are more discriminating than captive juveniles in their responses, resuming non-alert behaviour (like foraging) sooner when the playback stimulus is associated with less threat, but remaining alert longer when the stimulus indicates greater threat (e.g. a whistle alarm call or overhead visual object). Aerial-object playbacks elicited similar responses from both groups of juveniles, suggesting that environmental effects on alarm-call response behaviour were limited to auditory stimuli alone.

In contrast to juveniles, the responses of captive mothers, which were born and reared in the field but observed in the enclosures, did not differ appreciably from those of free-living mothers, suggesting that responses are more plastic early in development. The adult contrast also indicates that the captive testing environment used, outdoor enclosures designed as a semi-natural environment, did not induce species-atypical behaviour. Collectively, our results support the idea that by rearing and observing ground squirrels in an appropriate artificial environment one can gain ecologically valid insights into the ontogeny of behavioural responses to antipredator calls.

The response differences found between free-living and captive $S$. beldingi juveniles might be explained by a simple density effect, because the proximity of conspecifics can have short-term effects on the antipredator responses of many species (Elgar 1989; Lima \& Dill 1990; Loughry 1993; Hoogland 1995; Mateo 1996b). For instance, captive juveniles housed at low density (two mothers and 810 juveniles) remained alert significantly longer after playbacks than high-density juveniles (four mothers and 16 juveniles), but density had no significant effect 
on responsivity to playbacks (Mateo 1995). Thus, because low-density juveniles exhibited heightened responses relative to high-density juveniles in prior work, differences in density may help explain the contrast found between captive- and field-reared young. However, the captive juveniles in this study, which also gave exaggerated responses, lived at a higher, not lower, density than the free-living juveniles studied $\left(\approx 0.032\right.$ animals $/ \mathrm{m}^{2}$ and $0.007 / \mathrm{m}^{2}$, respectively). If conspecific density was crucial to the juveniles' responses, then captive juveniles should have displayed a reduced response relative to free-living juveniles, but they did not. Further, free-living juveniles may be $>15 \mathrm{~m}$ from the nearest conspecific when they hear an alarm call, which is a greater distance than is possible in an enclosure. Therefore, differences in the presence and proximity of conspecifics do not satisfactorily explain the differences in alarm-call response behaviour between freeliving and captive juveniles described here. In a companion paper (Mateo \& Holmes 1999), we examine other factors that might explain the differences found.

What do the quantitative differences found between free-living and captive juveniles reveal about the process of alarm-call response development? Free-living juveniles responded differentially to alarm calls and non-alarm calls at an earlier age than captive young (Fig. 2). This difference of 1-2 d demonstrates an effect of the early environment on the rate of acquisition of discrimination abilities and reveals that the process of development is mediated by the unique features of an individual's environment or ontogenetic niche. That response differences between free-living and captive juveniles were evident within $1 \mathrm{wk}$ of emergence and persisted at least until autumnal immergence reveals that the outcome of development is also influenced by the unique features of an individual's ontogenetic niche.

Our results with juvenile ground squirrels indicate that the ontogeny of alarmcall responses, and perhaps survival skills in general, is not invariant or preprogrammed, but instead is a product of many kinds of stimulation and exposure that developing animals experience (Miller 1981; West \& King 1987). There were several differences between the field and captive environments, such as the kind and amount of stimulation prior to natal emergence, the availability of food, and the frequency of exposure to alarm calls and predators, among others. The data reported above do not allow us to identify which environmental factor(s) mediated the response differences reported, nor can we determine whether pre- and/or postemergent experiences influenced the development of response differences between the two environments. Therefore, the general goal of our companion paper (Mateo \& Holmes 1999) was to examine the kinds of stimulation and exposure that might explain the contrasts in alarm-call response development reported here.

\section{Acknowledgements}

This research was supported by a National Science Foundation Dissertation Improvement Grant (IBN-9311508) as well as funding from Sigma Xi, American Society of Mammalogists and Rackham School of Graduate Studies to JMM and National Institute of Mental Health (MH 43861) and the University of Michigan's Office of the Vice President of Research to WGH. We thank A. Bell, M. Clancy, J. Osborn and L. Starr for their assistance in collecting the data discussed here. We also thank D. Leger for sharing his collection of $S$. beldingi alarm-call recordings with us, and D. Dawson, director 
of SNARL, for his encouragement and co-operation. G. Gerstner, R. Johnston, T. Lee, J. Mitani, B. Smuts and two reviewers provided stimulating comments on previous versions of the manuscript.

\section{Literature Cited}

Alberts, J. R. 1987: Early learning and ontogenetic adaptation. In: Perinatal Development: A Psychobiological Perspective (Krasnegor, N. A., Blass, E. M., Hofer, M. A. \& Smotherman, W. P., eds). Academic Press, Orlando, pp. 11-37.

Beecher, M. D. 1996: Birdsong learning in the laboratory and field. In: Ecology and Evolution of Acoustic Communication in Birds (Kroodsma, D. E. \& Miller, E. H., eds). Cornell Univ. Press, Ithaca, pp. $61-78$.

Brodie, E. D. III 1993: Consistency of individual differences in anti-predator behaviour and colour pattern in the garter snake, Thamnophis ordinoides. Anim. Behav. 45, 851-861.

Brown, M. M., Kreiter, N. A., Maple, J. T. \& Sinnott, J. M. 1992: Silhouettes elicit alarm calls from captive vervet monkeys (Cercopithecus aethiops). J. Comp. Psychol. 106, 350-359.

Elgar, M. A. 1989: Predator vigilance and group size in mammals and birds: a critical review of the empirical evidence. Biol. Rev. 64, 13-33.

Endler, J. A. 1991: Interactions between predators and prey. In: Behavioural Ecology (Krebs, J. R. \& Davies, N. B., eds). Blackwell Sci. Publ., Boston, pp. 169-201.

Endler, J. A. 1995: Multiple-trait coevolution and environmental gradients in guppies. Trends. Ecol. Evol. 10, 22-29.

Galef, B. G. Jr 1981: The ecology of weaning: parasitism and the achievement of independence by altricial mammals. In: Parental Care in Mammals (Gubernick, D. J. \& Klopfer, P. H., eds). Plenum Press, New York, pp. 211-241.

Goodey, W. \& Liley, N. R. 1986: The influence of early experience on escape behaviour in the guppy. Can. J. Zool. 64, 885-888.

Holekamp, K. E. 1984: Natal dispersal in Belding's ground squirrel (Spermophilus beldingi). Behav. Ecol. Sociobiol. 16, 21-30.

Holmes, W. G. 1994: The development of littermate preferences in juvenile Belding's ground squirrels. Anim. Behav. 48, 1071-1084.

Hoogland, J. L. 1995: The Black-tailed Prairie Dog: Social Life of a Burrowing Mammal. Univ. of Chicago Press, Chicago.

Jenkins, S. H. \& Eshelman, B. D. 1984: Spermophilus beldingi. Mamm. Species 221, 1-8.

Klump, G. M. \& Shalter, M. D. 1984: Acoustic behaviour of birds and mammals in the predator context. II. The functional significance and evolution of alarm signals. Z. Tierpsychol. 66, 206226.

Leger, D. W., Berney-Key, S. D. \& Sherman, P. W. 1984: Vocalizations of Belding's ground squirrels (Spermophilus beldingi). Anim. Behav. 32, 753-764.

Leger, D. W. \& Didrichsons, I. A. 1994: An assessment of data pooling and some alternatives. Anim. Behav. 48, 823-832.

Lima, S. L. \& Dill, L. M. 1990: Behavioral decisions made under the risk of predation: a review and prospectus. Can. J. Zool. 68, 618-640.

Loughry, W. J. 1993: Determinants of time allocation by adult and yearling black-tailed prairie dogs. Behaviour 124, 23-43.

Magurran, A. E. 1990: The inheritance and development of minnow antipredator behaviour. Anim. Behav. 39, 834-842.

Martin, P. \& Bateson, P. 1986: Measuring Behaviour. Cambridge Univ. Press, Cambridge.

Mateo, J. M. 1995: The development of alarm-call responses in free-living and captive Belding's ground squirrels, Spermophilus beldingi. PhD Diss., Univ. of Michigan, Ann Arbor.

Mateo, J. M. 1996a: Early auditory experience and the ontogeny of alarm-call discrimination in Belding's ground squirrels (Spermophilus beldingi). J. Comp. Psychol. 110, 115-124.

Mateo, J. M. 1996b: The development of alarm-call response behaviour in free-living juvenile Belding's ground squirrels. Anim. Behav. 52, 489-505.

Mateo, J. M. \& Holmes, W. G. 1997: Development of alarm-call response behaviour in juvenile Belding's ground squirrels: the role of dams. Anim. Behav. 54, 509-524. 
Mateo, J. M. \& Holmes, W. G. 1999: How rearing history affects alarm-call responses of Belding's ground squirrels (Spermophilus beldingi, Sciuridae). Ethology 105, 207-222.

Miller, D. B. 1981: Conceptual strategies in behavioral development: normal development and plasticity. In: Behavioral Development (Immelmann, K., Barlow, G. W., Petrinovich, L. \& Main, M., eds). Cambridge Univ. Press, New York, pp. 58-85.

Miller, D. B. 1994: Social context affects the ontogeny of instinctive behaviour. Anim. Behav. 48, 627634.

Murie, J. O. \& Boag, D. A. 1984: The relationship of body weight to overwinter survival in Columbian ground squirrels. J. Mamm. 65, 688-690.

Owings, D. H. \& Coss, R. G. 1977: Snake mobbing by California ground squirrels: adaptive variation and ontogeny. Behaviour 62, 50-69.

Poran, N. S. \& Coss, R. G. 1990: Development of antisnake defenses in California ground squirrels (Spermophilus beecheyi): I. Behavioral and immunological relationships. Behaviour 112, 222-245.

Robinson, S. R. 1980: Antipredator behaviour and predator recognition in Belding's ground squirrels. Anim. Behav. 28, 840-852.

Robinson, S. R. 1981: Alarm communication in Belding's ground squirrels. Z. Tierpsychol. 56, 150 168.

Rowell, T. E. 1967: A quantitative comparison of the behaviour of a wild and caged baboon group. Anim. Behav. 15, 499-509.

Sherman, P. W. 1976: Natural selection among some group-living organisms. PhD Diss., Univ. of Michigan, Ann Arbor.

Sherman, P. W. 1977: Nepotism and the evolution of alarm calls. Science 197, 1246-1253.

Sherman, P. W. 1985: Alarm calls of Belding's ground squirrels to aerial predators: nepotism or selfpreservation? Behav. Ecol. Sociobiol. 17, 313-323.

Sherman, P. W. \& Morton, M. L. 1984: Demography of Belding's ground squirrels. Ecology 65, 16171628.

Trombulak, S. C. 1991: Maternal influence on juvenile growth rates in Belding's ground squirrel (Spermophilus beldingi). Can. J. Zool. 69, 2140-2145.

Tulley, J. J. \& Huntingford, F. A. 1987: Parental care and the development of adaptive variation in anti-predator responses in sticklebacks. Anim. Behav. 35, 1570-1572.

West, M. J. \& King, A. P. 1987: Settling nature and nurture into an ontogenetic niche. Dev. Psychobiol. 20, $549-562$.

Received: December 17, 1997

Initial acceptance: July 24, 1998

Final acceptance: September 4, 1998 (J. Brockmann) 